\title{
Improving the Economic Literacy of Entrepreneurs with Technical Competencies
}

\author{
Magomed Magomedov ${ }^{1},{ }^{*}$ Ol'ga Karabanova ${ }^{1}$, Elena Aleksejcheva ${ }^{1}$, Elena \\ Kulomzina ${ }^{1}$
}

\author{
${ }^{1}$ Moscow City University, Moscow, Russia \\ *Email: profmagomedov@mail.ru
}

\begin{abstract}
Technological entrepreneurship is one of the most critical research areas in the modern economy due to the significant contribution of rapidly growing companies to the economic growth of the country and regions of the world. Identifying factors affecting the success and effectiveness of startups will allow regulating tools to support and stimulate entrepreneurship in high technologies and innovations. The article considers the historical aspect of citizens' transition with engineering competencies into entrepreneurial activity, their adaptation to market processes. In the study, there is a hypothesis about the importance of economic and managerial education for technological entrepreneurs, entrepreneurs with technical competencies. Attention is drawn to the need for engineers to master economic competencies to improve their work efficiency in entrepreneurship. It is proposed to pay great attention to the full-fledged retraining of engineers to acquire economic competencies in the created courses. Specific measures to solve it are recommended. The necessity of improving the quality of products and services provided by enterprises is substantiated. The importance of conducting an effective pricing policy by an enterprise is considered.
\end{abstract}

Keywords: Engineer, Entrepreneurship, Economic competencies, Retraining courses, Quality of products and services provided, Pricing policy.

\section{INTRODUCTION}

According to Startup Genome research, the global startup economy is currently overgrowing and is estimated at \$2.8 trillion from 2016 to 2018 [1]. However, Russian technological entrepreneurship has its peculiarities, mainly due to its difficult formation period. After the beginning of the transition of the Russian Federation (RF) to market relations, many citizens of the country began to engage in various types of entrepreneurial activity. Not all of them had an economic education and, accordingly, made many mistakes in practice. It is impossible to blame them since even economists did not fully understand working in a market economy. At first, many Russians imagined the market economy as the purchase and sale of goods, heavily prohibited in a planned economy. I.e. in the Criminal Code of the RSFSR, there was a separate article (Article 154 of the Criminal Code of the RSFSR) for speculation.
Therefore, when they were given such an opportunity, a significant number of citizens of the country began to resell both food and industrial goods. Using only this type of entrepreneurship, the Russian economy could not develop. This approach, on the contrary, led to an acceleration of the pace of crisis phenomena. As a result, this led to the country's default (in the summer of 1998). After that, gradually, citizens began to engage in the development of the country's economy. However, such development was carried out very slowly. This was due to both objective and subjective reasons. The objective ones include the lack of a scientifically sound legislative framework for the functioning of existing and newly created enterprises in a market economy, a slow change in the outlook of citizens of the country to the perception of a market economy. There was a lack of the necessary quantity and quality of competencies among the population wishing to engage in entrepreneurship. The subjective reasons were: the unwillingness of people to 
engage in entrepreneurship, lack of work experience in a market economy, etc.

The analysis showed that many citizens with excellent knowledge in their narrow specialities (teachers, doctors, engineers, etc.) cannot always engage in entrepreneurship due to the limited necessary competencies. As you know, there are three main types of entrepreneurial activity: production, commercial and financial. Despite their independence, they are strongly interconnected [2]. Industrial entrepreneurship is aimed at the production of certain types: products, goods, works, services and the creation of specific intellectual values. They should be implemented to ensure extended and straightforward reproduction in the enterprise. It is impossible to do without conducting competent marketing research and an effective pricing policy in such conditions. In commercial entrepreneurship, citizens of the country are engaged exclusively in trade and intermediary activities and the sale of goods and services. When developing this form, it is also necessary to possess competencies related to marketing research and effective pricing policy [3]. In addition, citizens engaged in this type of entrepreneurship should have the ability to introduce trade activities for the sale of goods and services.

\section{FEATURES OF DOING BUSINESS IN RUSSIA}

Our analysis of the implementation of a large number of trade and intermediary operations showed that the lion's share of the profits of manufacturers of products and firms providing services is absorbed by entrepreneurs engaged in this type of entrepreneurship. In most cases, this leads to an increase in prices for goods and services for the end consumer by 2-3 times to the initial ones, which subsequently affects not only a decrease in the profits of producers but also an inevitable decrease in demand for manufactured products and services [4]. With the acceleration of inflation, the probability of deterioration of the financial condition of companies increases significantly. In such conditions, entrepreneurs who produce products and provide services tend to avoid the help of firms engaged in trade and intermediary activities as much as possible. Financial entrepreneurship is associated with the purchase and sale of securities (stocks, bonds, promissory notes, bank certificates), currency valuables (stocks, bonds, letters of credit, checks, promissory notes, and other debt obligations in foreign currency, foreign currency, precious stones in raw and processed form, precious metals and platinum group metals), national money (a monetary unit used in the territory of the relevant state. In the Russian Federation, the ruble.). For the effective introduction of financial entrepreneurship, it is necessary to have high-level economic competencies.

\section{SPECIFICS OF DOING BUSINESS BY ENGINEERS}

Specialists with engineering competencies can engage in any of these forms of entrepreneurship if they are highly qualified. Qualified engineers have relatively well-developed logical thinking. From our point of view, such engineers will need a little time to master economic competencies.

From 1970 to 1985 , the number of trained, highly qualified engineers in the USSR increased markedly. They were graduates of a large number of well-known technical higher educational institutions (universities). These include Moscow State Technical University named after N.E. Bauman, Moscow State Institute of Physics and Technology (National Research University), Moscow Aviation Institute (National Research University), etc. [5]. In these and several other universities, engineers were trained, at that time, corresponding to the demand on world markets. Starting in 1985, a gradual deterioration in the quality of trained engineers began. After the beginning of the country's transition to market relations, many enterprises were closed. Some - for objective reasons (that is, products were produced that did not meet the demand on domestic and foreign markets), and others - for subjective reasons (by decision of the country's leadership, criminal groups). As a result, a significant number of highly qualified engineers were forced to switch to jobs that did not correspond to their education. Subsequently, they gradually began to lose their qualifications. I.e. those engineers engaged in creating spaceships were forced to participate in producing low-quality household appliances. And many of them got a job or were forced to do an unusual job for them - reselling goods and services. As a result, many highly qualified engineers were lost, who could create many types of products in great demand on the world market. This is confirmed by the results obtained in the defence industry of our country. In such conditions, radical changes in the country's economy for the better are possible with the introduction of new and reconstruction of existing enterprises that will work on new advanced equipment and with the use of new technologies. And this requires not only significant financial resources but also highly qualified engineers. The country's current economic state allows us to provide state support to universities engaged in engineering training. However, there is still a large number of highly qualified engineers but not working in their speciality. A significant part of them is engaged in various types of entrepreneurship [6]. The results of their activities do not always correspond to real opportunities. The main reason for this situation is their lack of the necessary economic competencies required to find the most effective management solutions to achieve high-end results of established and operating enterprises. 


\section{IMPROVING THE EFFICIENCY OF DOING BUSINESS BY ENGINEERS}

To solve this problem, from our point of view, it is necessary to improve the efficiency of the functioning of existing and newly created courses for retraining engineers. The analysis of many retraining courses for engineers at the country's leading universities showed that all the requirements are met in a small number of them. And in many cases, it is carried out formally; that is, they take a decent amount of money for training and do not give the necessary knowledge. This is because teachers of not the highest qualifications are involved in the retraining. In addition, the discipline of attending classes by students does not meet the requirements, and it is desirable to use business games of an economic profile based on empirical data in the learning process itself. To solve this problem, we cannot do without state intervention. The competent state authorities should increase the requirements for issuing a certificate of completion of retraining courses for engineers [7]. In addition, the state should stimulate the educational institution by allocating additional financial resources when working to improve the quality of retraining of engineers. It can be estimated by the number of wellknown domestic and foreign economic scientists involved in this case and specialists from practice with extensive experience in economic areas and leadership positions. The analysis results showed that the degree of assimilation of economic competencies by engineers increases significantly with this approach. Without severe financial support from the state, it is impossible to ensure the same indicators in other places of retraining of engineers created based on educational institutions [8]. At the same time, the allocation of financial resources for the qualitative implementation of the retraining program of engineers in an educational institution should be carried out according to scientifically based criteria and indicators. The financial resources allocated from the state budget to solve this problem will pay off within a short time due to accelerating the pace of development of the country's economy. The question arises, what disciplines should be in the retraining program for engineers? [9]. The answer to it should be sought in the peculiarities of the development of the market economy. In the current conditions of the development of the Russian economy, the main task of any enterprise is to increase its competitiveness.

\section{WAYS TO INCREASE COMPETITIVENESS}

\section{It can be solved in two ways:}

1. Improving the quality of products or services provided;

2. Conducting an effective pricing policy.
Let's consider these methods in more detail separately.

1. Improving the quality of products or services provided.

All disciplines aimed at improving the quality of products or services provided should be included in the retraining program for engineers. It is much easier for engineers to master the issues of improving the quality of products or services provided since they were constantly engaged in this (before starting a business). Only they need to be approached from an economic point of view. It often happens that an innovation related to improving the quality of products or services provided is not always economically advantageous. If economic calculations confirm the inexpediency of its use, then it should be abandoned. Everything related to improving equipment and technology to produce products and services, which leads to increased quality and a payback period corresponding to acceptable standards, should be used in practice. Demand for products and services of the best quality, as a rule, is high.

A decrease in the solvency of the country's population may be a break [10]. It is especially pronounced during the crisis periods of the country's economic development. A small number of entrepreneurs go to an inevitable deterioration in the quality of products and services provided to improve their financial condition for a short time. It negatively affects the subsequent development of the enterprise due to the deterioration of its reputation. It can be challenging to return customers to the products and services provided back to such enterprises. In modern conditions in the Russian Federation, when the market of goods and services is saturated quite well, buyers' requirements for their quality are growing significantly. Therefore, even minor deviations from the required quality standards lead to negative economic results for enterprises. They become, very quickly, the property of many buyers. Information technologies play a significant role in this matter. For example, before purchasing a product, a buyer can study reviews on it on the Internet and then decide whether to buy it or not. In addition, there are several other sources of information about the quality of goods and services provided [11]. The company itself can organize a population survey to determine the degree of their satisfaction with the quality of products or services provided. If deviations from the requirements are detected, they should be corrected promptly. Engineers engaged in entrepreneurship should not allow the deterioration of the use of existing equipment and technology for the production of products or services provided, as this may harm the economic results of the enterprise. In addition, the manufactured products must be stored in strict accordance with the requirements.

2. Conducting an effective pricing policy. 
The price of the manufactured products or services provided by the enterprise has a significant impact on its competitiveness. An engineer engaged in entrepreneurial activity must possess full economic competencies to conduct an effective pricing policy.

\section{PRICING FEATURES}

The wholesale and selling price of products consists of the following elements: 1 . The cost of production; 2 . Profits; 3. Value-added tax; 4. Excise taxes. The task of any enterprise is to maximize the profit received. From a theoretical point of view, this could be done by increasing the share of profit in the price. In such a situation, it may increase significantly and, accordingly, there will be problems with the sale of products. And if you increase the profit of the enterprise by reducing the cost of production and increasing the volume of products sold, you can solve this problem. When considering the issues of reducing the cost of production, it is necessary to conduct a detailed analysis of each calculation item and identify the possibilities of reducing costs for them. However, it should be borne in mind that reducing the consumption of raw materials below the established norm will lead to a deterioration in the quality of manufactured products, which will subsequently harm the economy of the enterprise. One of the main factors influencing the production process is labour resources. When qualified, experienced, and interested workers work at the enterprise, the probability of producing products of the required quality increases. Staff turnover increases with the infringement of employees' material interest in achieving the enterprise's high final performance, harming the economy. To prevent it, they should be set wages at the level of competitor enterprises. Losses of raw materials and defective products in the production process should be reduced to zero, as they increase the cost of production. Electrical energy is required for the implementation of the production process. With its help, technological machines and equipment are activated, as well as rooms are illuminated. It is possible to reduce the consumption of electric energy at the enterprise by eliminating the idling of technological machines and equipment and using energy-saving lamps for lighting the premises.

In addition, for other calculation items, an in-depth analysis should be carried out to reduce costs. The amount of value-added tax and excise tax rates (if the goods are excisable) do not depend on the company but are approved by the President of the Russian Federation. The amounts required by law are transferred to the state budget. With the full use of the available reserves to reduce the cost of production, the size of the price depends on the amount of profit included in it. With a large amount of profit, the price of manufactured products increases and vice versa. Before setting the price for its products, the company must conduct marketing research to determine the supply and demand and raw materials (necessary for its production). There are many technologies for conducting marketing research that an entrepreneur should know and be able to use in practice to achieve high economic indicators. In addition, an entrepreneur should know how and how much taxes and other payments should be transferred to the state budget. Recently, quite justifiably, they have been paying great attention to fire safety at the enterprise. For this, the equipment and technologies are currently being used, and entrepreneurs should own them. There are no problems for specialists with engineering competencies to master innovations in this area.

\section{CONCLUSIONS}

The analysis made it possible to conclude that it is necessary to master special competencies within the framework of additional education for the effective implementation of technological entrepreneurship. Such education should be carried out continuously, using new digital technologies, the program should be updated. The directions allowing to increase efficiency and cost of technology startups are revealed. The following disciplines must be included in the retraining program of engineers: 1. Analysis of the economic activity of the enterprise; 2. Marketing; 3. Pricing 4. Taxes and taxation; 5. Progressive technology and technology of production and provision of services; 6 . Methods for determining the quality of products and services provided; 7. Information technologies; 8. Strategic development of the enterprise; 9. Fire safety.

\section{REFERENCES}

[1] Global Startup Ecosystem Report 2019 [Electronic resource].

URL: https://startupgenome.com/(accessed: 10/30/2020)

[2] O.V. Karabanova, Formation of competencies of financial and legal literacy of technological entrepreneurs [Formirovanie kompetencij finansovoj i pravovoj gramotnosti tekhnologicheskih predprinimatelej], Continuing education in the context of the Future: A collection of scientific articles based on the IV International Scientific and Practical Conference materials [Nepreryvnoe obrazovanie v kontekste Budushchego: Sbornik nauchnyh statej po materialam IV Mezhdunarodnoj nauchnoprakticheskoj konferencii], Moscow, 2021, pp. 149153.

[3] O.V. Karabanova, M.D. Magomedov, O.V. Shinkareva, Practice-oriented training of technology entrepreneurs as a means of reducing risks for a startup [Praktikoorientirovannoe obuchenie tekhnologicheskih predprinimatelej kak sredstvo 
snizheniya riskov dlya startapa], Bulletin of the Catherine Institute [Vestnik Ekaterininskogo instituta] 3(55) (2021) 61-67.

[4] D.E. Tolmachev, Technological Entrepreneurship in Russian Regions: Educational and geographical trajectories of startup founders [Tekhnologicheskoe predprinimatel'stvo $\mathrm{v}$ rossijskih regionah: obrazovatel'nye i geograficheskie traektorii osnovatelej startapov] / D.E. Tolmachev, K.V. Chukavina // The region's economy [Ekonomika regiona] 16(2) (2020) 420-434. DOI: https://doi.org/10.17059/2020-2-7

[5] O.V. Karabanova, S.A. Sharapova, M.D. Magomedov, Competitiveness of a Multicultural Region's Economy: Measuring and Provision, Public Administration and Regional Management in Russia, Challenges and Prospects in a Multicultural Region, Switzerland: Springer Nature, 2020, pp. 163-172. DOI: https://doi.org/10.1007/978-3-03038497-5_19

[6] M.D. Magomedov, O.V. Karabanova, V.V. Stroev, Impact of Information and Communication Technologies Development on the Labor Market in the Russian Federation, Proceedings of the 2nd International Scientific and Practical Conference on Digital Economy (ISCDE 2020), Yekaterinburg, 0506 November 2020 / ed. Dr Anton Nazarov, Yekaterinburg: Institute of Digital Economics, 2020, pp. 297-300. DOI: https://doi.org/10.2991/aebmr.k.201205.049

[7] O.V. Karabanova, Improving financial and legal literacy of managers of small innovative enterprises in modern conditions. Continuing education in the context of the idea of the Future: new literacy: A collection of scientific articles based on the materials of the III International Scientific and Practical Conference [Povyshenie finansovoj i pravovoj gramotnosti rukovoditelej malyh innovacionnyh predpriyatij $\mathrm{v}$ sovremennyh usloviyah. Nepreryvnoe obrazovanie v kontekste idei Budushchego: novaya gramotnost': Sbornik nauchnyh statej po materialam III Mezhdunarodnoj nauchno-prakticheskoj konferencii], Moscow, June 18-19, 2020 / Compiled by N.I. Shevchenko, Moscow: A-Prior Limited Liability Company, 2020, pp. 333-335.

[8] E.Yu. Kulomzina, O.V. Shinkareva, Entrepreneurial literacy in taxation: aspects of tax optimization of planning as an essential condition for effective entrepreneurship, Continuing education in the context of the Future: A collection of scientific articles based on the materials of the IV International Scientific and Practical Conference
[Predprinimatel'skaya gramotnost' V oblasti nalogooblozheniya: aspekty nalogovoj optimizacii planirovaniya kak neot"emlemoe uslovie effektivnogo predprinimatel'stva, Nepreryvnoe obrazovanie v kontekste Budushchego: Sbornik nauchnyh statej po materialam IV Mezhdunarodnoj nauchno-prakticheskoj konferencii], Moscow, April 21-22, 2021, pp. 336-342.

[9] O.A. Lomovtseva, Prospects and problems of development of the city model of universities in Russia [Perspektivy i problemy razvitiya siti-modeli universitetov v Rossii] / O.A. Lomovtseva, O.V. Shinkareva, D.M. Sulimova // Bulletin of the Catherine Institute [Vestnik Ekaterininskogo instituta] 2(54) (2021) 56-62.

[10] O.V. Karabanova, Improving the effectiveness of measures to support small businesses in Moscow during the pandemic [Povyshenie rezul'tativnosti mer podderzhki malogo biznesa v gorode Moskve v period pandemii] / O.V. Karabanova, E.Yu. Grigorieva // Society, economics and law: challenges of modernity and development trends: a collection of articles based on the materials of the II International Scientific and Practical Conference [Obshchestvo, ekonomika i pravo: vyzovy sovremennosti i tendencii razvitiya: sbornik statej po materialam II Mezhdunarodnoj nauchnoprakticheskoj konferencii], Volzhsky, December 24, 2020, pp. 116-118.

[11]E.G. Lanina, Features and resource support of modern technological entrepreneurship [Osobennosti i resursnoe obespechenie sovremennogo tekhnologicheskogo predprinimatel'stva] / E.G. Lanina // Digital Economy and Finance: IV International Scientific and Practical Conference materials [Cifrovaya ekonomika i finansy: materialy IV Mezhdunarodnoj nauchno-prakticheskoj konferencii], March 18-19, St. Petersburg: Center for Scientific and Production Technologies "Asterion", 2021, pp. 125-130. 